\title{
New Anti-Chemokine Oral Drug XC8 in the Treatment of Asthma Patients with Poor Response to Corticosteroids: Results of a Phase 2A Randomized Controlled Clinical Trial
}

\author{
Julia Romanova (D) - Elena Chikina · Anastasia Rydlovskaya • \\ Wolfgang Pohl · Andreas Renner · Alexey Zeifman · Alexander Chuchalin • \\ Vladimir Nebolsin
}

Received: June 24, 2020 / Accepted: September 26, 2020 / Published online: October 23, 2020

(c) The Author(s) 2020

\section{ABSTRACT}

Introduction: A significant number of patients with moderate asthma remain symptomatic despite treatment with inhaled corticosteroids (ICS). These patients do not yet meet the criteria for oral corticosteroids (OCS) and monoclonal antibodies. The new anti-chemokine oral drug XC8 could represent an alternative treatment option for these patients. The objective of this trial was to evaluate the effect of different doses of the XC8 in patients with partly controlled asthma in a phase 2 a clinical trial.

Electronic supplementary material The online version of this article (https://doi.org/10.1007/s41030020-00134-5) contains supplementary material, which is available to authorized users.

J. Romanova $(\square)$

EURRUS Biotech GmbH, Tulln, Austria

e-mail: jr.romanova@gmail.com

E. Chikina · A. Rydlovskaya · V. Nebolsin

PHARMENTERPRISES LLC, Moscow, Russia

W. Pohl · A. Renner

Karl Landsteiner Institute for Clinical and

Experimental Pneumology, Hietzing Hospital,

Vienna, Austria

\section{A. Zeifman}

Chemimmune Therapeutics LLC, Moscow, Russia

A. Chuchalin

Institute of Pulmonology, Federal Medical and

Biological Agency, Moscow, Russia
Methods: A double-blind, parallel-group, randomized, multicenter, phase $2 \mathrm{a}$ trial was conducted at 12 sites in Russia. Patients with asthma were randomized into four groups $(n=30$ each) to receive XC8 at $2 \mathrm{mg}, 10 \mathrm{mg}$, $100 \mathrm{mg}$ or placebo once-daily for 12 weeks in addition to low-dose ICS with or without LABA. Efficacy and safety parameters were evaluated at weeks $0,2,6$, and 12 .

Results: No statistically significant difference between the treatment arms in the number of patients with adverse events was observed. The primary endpoint, improvement of forced expiratory volume in $1 \mathrm{~s}\left(\mathrm{FEV}_{1}\right) \%$ predicted over 12 weeks compared to placebo, was not statistically significant. The treatment of patients with XC8 $(100 \mathrm{mg})$ resulted in statistically and clinically significant improvements in $\mathrm{FEV}_{1}$ compared to baseline $(7.40 \%$ predicted, $p<0.001)$. Patients with elevated peripheral blood eosinophil count (PBEC, $>300$ cells $/ \mu \mathrm{l}$ ) or serum interferon- $\gamma$ (IFN- $\gamma$ ) level $(>100 \mathrm{pg} /$ $\mathrm{mL})$ treated with XC8 (100 mg) achieved a statistically significant improvement in $\mathrm{FEV}_{1}$ (11.33\% predicted or $8.69 \%$ predicted, respectively, $p<0.05)$ as compared to the baseline versus the placebo. The strongest effect was observed in patients with both high PBEC and IFN- $\gamma$ level. Pharmacodynamic engagement was demonstrated through the reduction of serum levels of $\mathrm{C}-\mathrm{C}$ motif ligand 2 (CCL2) and $\mathrm{C}-\mathrm{X}-\mathrm{C}$ motif chemokine 10 (CXCL10). Treatment with XC8 (100 mg) alleviated resistance to 
maintenance ICS therapy in patients with elevated IFN- $\gamma$ level.

Conclusions: Given the high safety, oral route of administration, and efficacy, XC8 may provide a promising treatment option for patients with mild-to-moderate asthma.

Trial Registration: 795-30/12/2015 (Ministry of Health Russian Federation), NCT03450434 (ClinicalTrials.gov).

Keywords: Asthma; Chemokine; Corticosteroid resistance; Eosinophils; Interferongamma; XC8

\section{Key Summary Points}

The treatment of patients with XC8 100 mg over 12 weeks resulted in statistically and clinically significant increase in $\mathrm{FEV}_{1}$ by 0.24 liters and $7.40 \%$ predicted compared to the baseline.

The treatment of patients with elevated PBEC ( $>300$ cells/ $\mu$ l) and/or IFN- $\gamma$ level $(>100 \mathrm{pg} / \mathrm{mL}$ ) with XC8 at $100 \mathrm{mg}$ over 12 weeks resulted in statistically significant increase in $\mathrm{FEV}_{1}$ (\% predicted) compared to the baseline versus placebo.

Pharmacodynamic engagement was demonstrated through the reduction of serum levels of C-C motif ligand 2 (CCL2) and $\mathrm{C}-\mathrm{X}-\mathrm{C}$ motif chemokine 10 (CXCL10).

Treatment with XC8 (100 mg) alleviated resistance to maintenance ICS therapy in patients with a high IFN- $\gamma$ level

\section{DIGITAL FEATURES}

This article is published with digital features, including a summary slide, to facilitate understanding of the article. To view digital features for this article go to https://doi.org/10.6084/ m9.figshare.13007351.

\section{INTRODUCTION}

With more than 300 million patients affected, asthma remains one of the most widespread chronic diseases [1]. Despite the large number of treatment options available on the market for asthma, supportive therapy during remissions remains one of the key problems due to limited efficacy of existing solutions. Treatment of asthma mainly comprises control over the clinical manifestations of the disease as per Global Initiative for Asthma (GINA 2015) guidelines [2]. Drugs used for the treatment of asthma include maintenance therapy and relievers [3]. The administration of maintenance drugs is daily and long-term in most patients. This group of drugs includes inhaled corticosteroids (ICS) and systemic oral corticosteroids (OCS), antileukotrienes, and longacting inhaled $\beta 2$-agonists (LABA) in combination with ICS [4]. A significant number of patients with moderate asthma remain symptomatic despite ICS or other maintenance therapy. These patients do not have adequate asthma control but do not yet fulfill the criteria for treatment with monoclonal antibodies (mAbs) and OCS. They are also often not adherent to ICS therapy. Therefore, an oral drug would be well received by these patients. Prostaglandin D2 (DP2) receptor antagonists hold promise for addressing this unmet need, demonstrating good efficacy combined with oral bioavailability. However, several late-stage clinical failures of this class of compounds [5], including the recent failure of the DP2 antagonist Fevipiprant in phase 3 reported by Novartis, keep an unmet medical need for a safe oral drug for asthma in place.

According to Douwes et al., approximately $50 \%$ of asthma patients have an eosinophilic phenotype of disease [6], which is occasionally challenging to treat (reviewed in [7]). The management of patients with uncontrolled eosinophilic asthma is almost twofold more expensive compared to patients with normal peripheral blood eosinophil count (PBEC) [8]. Elevated PBEC have also been shown to be associated with an increased frequency of asthma exacerbations [9]. Novel therapeutics- 
mAbs targeting key mediators of type 2 eosinophilic asthma as interleukin-4 (IL-4), IL-5, IL13 , as well as anti-IL receptors IL- $4 \mathrm{R} \alpha$ (IL- $4 / \mathrm{IL}-$ 13), IL-5R, and thymic stromal lymphopoietin (TSLP) are being developed [10]. The metaanalyses revealed no statistically significant superiority of one $\mathrm{mAb}$ over the others $[11,12]$. MAbs, such as mepolizumab, reslizumab, and benralizumab blocking IL- 5/IL-5R were shown to be beneficial in the treatment of severe persistent eosinophilic asthma (step 4/5, GINA) [13-16]. Dupilumab targets IL-4R $\alpha$ and was shown to improve the clinical outcomes and quality of life of patients with moderate-tosevere asthma when used together with ICS [17]. However, the utility of mAbs for patients with moderate (step 3, GINA) disease is rather limited [3]. The high cost of the mAbs and parenteral route of administration are the main limiting factors for patients with moderate asthma $[18,19]$.

We have shown earlier that the derivatives of biogenic amines (peptidoamines) are effective against some inflammatory diseases [20-22]. We have found that the glutarimide derivative XC8 reduces the influx of eosinophils into bronchoalveolar lavage (BAL) in a Sephadex-induced lung inflammation model in rats [23]. In a model of acute and chronic asthma, XC8 significantly reduced the number of eosinophils in BAL, degranulating mast cell and goblet cell number in the lung tissue and specific airway resistance. The mechanism of action of XC8 is related to the inhibition of Golgi-resident human glutaminyl cyclase (gQC), the enzyme, which catalyzes the pyroglutamination of chemokines of $\mathrm{C}-\mathrm{C}$ motif family (unpublished data). Pyroglutaminated chemokines CCL2, CCL8, CCL7, and CCL13 are involved in most inflammatory disorders including asthma [24]. One of their functions is the attraction of eosinophils $[25,26]$. Moreover, we showed that the treatment of mice stimulated with interferon- $\gamma$ (IFN- $\gamma$ ) with XC8 led to a decrease of neutrophils in the BAL, which correlated with the decrease of $\mathrm{C}-\mathrm{X}-\mathrm{C}$ motif chemokine 10 (CXCL10), known as IFN- $\gamma$ inducible protein (unpublished data). The phase 1 clinical trial of XC8 conducted in Europe in healthy volunteers in three dose-groups $(10,50$, and $200 \mathrm{mg})$ demonstrated its safety [27]. The single and multiple administration of XC8 for up to 14 days demonstrated good tolerability and a favorable safety profile for the dose range 10-200 mg without accumulation.

We hypothesize that the addition of XC8 to low doses of ICS could be a useful strategy to increase the efficacy of asthma maintenance therapy, in order to achieve control over the disease instead of increasing doses of ICS in patients with partly controlled asthma (GINA 2015 , box 2-2). The objective of this study was to evaluate the effect of different doses of the anti-chemokine oral drug XC8 in treatment of asthma patients with poor response to ICS in a randomized, double-blind, placebo-controlled phase 2a clinical trial.

\section{METHODS}

\section{Study Design}

The double-blind, parallel-group, randomized, multicenter, phase 2a trial (named PULM-XC802 ) was conducted at 12 sites in Russia. The trial comprised a 1-week screening period, 2-week run-in period, 12-week treatment period, and 4-week follow-up period. The trial enrolled 120 patients with asthma that met all of the inclusion criteria and did not have any exclusion criteria. At baseline, subjects with confirmed partly controlled asthma (according to GINA 2015 , see also below) were randomized to receive XC8 at 2,10, and $100 \mathrm{mg}$ or placebo at a ratio of 1:1:1:1 (30 patients per treatment arm).

The sample size was determined so that 104 patients complete the study (26 patients per treatment arm) if no more than $13 \%$ of patients discontinue early. This number of patients was deemed sufficient to compare the groups with the level of significance $\alpha=5 \%$, power $80 \%$, difference between groups $9 \%$, standard deviation (SD) $11.5 \%$, considering 30\% screen-failure rate, and 5\% withdrawal after the run-in period.

Randomization was done automatically with the use of Interactive Web Response System (IWRS). For the purpose of blinding, each patient simultaneously received three tablets corresponding to $2 \mathrm{mg}$ or placebo, $10 \mathrm{mg}$ or 
placebo, and $100 \mathrm{mg}$ or placebo. The patients received treatment with XC8 or placebo for 12 weeks in addition to maintenance therapy with low doses of ICS (GINA 2015 [2]) with or without LABA. ICS doses were categorized according to GINA 2015 (box 3-6), described in Supplementary Table S1.

The study drug was administered once a day 30 min before breakfast. Patients visited the site at week 0 , week 2 , week 6 , and week 12 to evaluate efficacy and safety parameters. Patients self-measured the peak expiratory flow (PEF) and maintained a diary where they recorded their asthma symptoms. At each visit, the data from the patient's diary and spirometry results were evaluated. At week 6 and week 12, a physical examination, vital signs examination, body weight measurement, and blood and urine sampling for laboratory tests were also performed. At week 12, the study treatment was completed.

\section{Participants}

Eligible subjects were non-smoking males and females between 18 and 65 (inclusively) years old with a diagnosis of asthma that was established at least 12 months prior to screening. The inclusion criteria were as follows:

1. Signed informed consent is obtained before performing any assessment.

2. Non-smoking males and females between 18 and 65 (inclusively) years old at the time informed consent is signed.

3. Physician diagnosis of asthma (as per GINA 2015 guidelines), made for at least 12 months prior to screening. The confirmed reversibility of asthma as rapid improvements in $\mathrm{FEV}_{1}$ (or PEF), measured within minutes after inhalation of a rapidacting bronchodilator (as per GINA 2015).

4. Continuous therapy with prescribed ICS with or without LABA for at least 3 months prior to screening (Step 2 and 3 as per GINA 2015).

5. Symptoms of partly controlled asthma for at least 4 weeks prior to screening (as per GINA 2015).
6. Patients with a pre-bronchodilator $\mathrm{FEV}_{1}$ value of $60 \%$ to $80 \%$ of individual predicted value at screening and randomization.

7. Signed informed consent is obtained to use effective methods of contraception throughout the study. The effective methods of contraception include:

- Established oral or implanted hormonal methods of contraception

- Barrier method: condom or occlusive cap with spermicide

- Intrauterine device

8. Ability to comply with all protocol requirements.

Patients with any of following exclusion criteria were not eligible for inclusion in the study:

1. Pregnant or lactating women or women of child-bearing potential not using effective contraception.

2. Smoking or ex-smoking patients who stopped within 1 year prior to screening or had smoking history of more 10 packyear.

3. Severe exacerbations or not controlled asthma for 3 months prior to screening.

4. Chronic obstructive pulmonary disease (COPD) or other lung diseases in addition to asthma.

5. Inflammatory diseases of mouth.

6. Acute respiratory infection within 30 days prior to screening.

7. Participation of patients in any clinical trial or use of any investigational products within 30 days prior to screening.

8. Patients receiving or likely to require treatment during the study with other drugs for treatment of asthma (including antileukotrienes and theophylline extended-release tablets), except those permitted by the protocol.

9. Patients receiving or likely to require treatment during the study with OCS, non-steroid anti-inflammatory agents, or agents affecting the immune system.

10. Patients receiving or likely to require treatment during the study with stable doses of antihistamines. 
11. Patients receiving or likely to require treatment during the study with immunosuppressant drugs within 3 months prior to screening.

12. Anaphylaxis, generalized urticarial, or angioedema within 1 year prior to screening.

13. History of allergy, hypersensitivity, or contraindication to XC8 or its components.

14. Systemic autoimmune diseases or collagen vascular disease in medical history.

15. History of malignancy within the past 5 years (except basal cell carcinoma).

16. Significant cardiac or vascular disease at the moment of screening or within 12 months prior to screening, including chronic heart failure according to New York Heart Association (NYHA) Class III or IV; severe arrhythmia requiring therapy with Class Ia, Ib, Ic and Class III antiarrhythmic drug; unstable angina; myocardial infarction; cardiac surgery and coronary artery bypass grafting; relevant cardiac valves disorders; transient ischemic attack or stroke; uncontrolled arterial hypertension with systolic pressure $>180 \mathrm{mmHg}$ and diastolic pressure $>110 \mathrm{mmHg}$; pulmonary embolism or deep vein thrombosis.

17. Nephrotic syndrome, moderate and severe chronic renal failure, or significant renal diseases with creatinine level of $>1.5 \mathrm{mg} /$ dl $(132 \mu \mathrm{mol} / \mathrm{l})$ in males and $>1.4 \mathrm{mg} / \mathrm{dl}$ $(123 \mu \mathrm{mol} / \mathrm{l})$ in females or glomerular filtration rate $(\mathrm{GFR})<60 \mathrm{~mL} / \mathrm{min}$.

18. Patients testing positive for human immunodeficiency virus (HIV), hepatitis $\mathrm{B}$ or $\mathrm{C}$, or with hepatic cirrhosis in history; elevated level of serum aspartate aminotransferase (ASAT) or alanine aminotransferase (ALAT) $\geq 3$ times of the upper limit of normal (UNL); elevated total bilirubin $\geq 2$ times of UNL at the screening.

19. Anemia (hemoglobin $\leq 10.5 \mathrm{~g} / \mathrm{dl}$ in females and $\leq 11.5 \mathrm{~g} / \mathrm{dl}$ in males); blood loss or donating blood $(\geq 500 \mathrm{~mL})$, or blood transfusion within 12 weeks prior to screening.
20. Any concomitant disease besides asthma which is not controlled with stable treatment.

21. Drug or alcohol abuse at the moment of screening or in the history.

22. Patients who are unable to read or to write; unwilling to understand and to follow the procedures of the study protocol; interfere with the therapy or procedures that, in the opinion of the investigator, could affect the results of the trial or safety of the patient and interfere with further participation in the trial; any other comorbid medical and serious mental conditions that render the patient ineligible for participation in the clinical study, or may affect the patient's ability to participate in the study.

During the trial, the patients were not allowed to take the following drugs:

- Changes in the asthma maintenance treatment.

- Systemic corticosteroids;

- Nonsteroidal anti-inflammatory drugs for more than three consecutive days of administration;

- Short- and long-acting anticholinergics;

- Sodium cromoglycate or nedocromil sodium, ketotifen, leukotriene modifiers, theophylline (in any pharmaceutical form);

- Anti IgE and IL-5/5R mAbs;

- Antihistamines;

- Beta-blockers, including eye drops;

- Immunosuppressive drugs;

- Cytochrome P450 inhibitors, microsomal oxidation inducers;

- Methandrostenolone, estrogens (except for low doses of estrogens in combined oral contraceptives).

All subjects provided written informed consent before participating in the study. The study was conducted in accordance with the principles of the Declaration of Helsinki and the International Conference on Harmonization Guidance for Good Clinical Practice. The study was approved by the Ethics Committee Ministry of Health of the Russian Federation, protocol 115 from 08.12.2015. 


\section{Investigational Product}

$\mathrm{XC} 8$ is a 1 (2-(1H-imidazol-4-yl) ethyl) piperidine-2,6-dione based on IUPAC nomenclature. The drug substance of XC8 was produced and released by Alven Laboratories (Czech Republic) according to current European Good Manufacturing Practice regulations. The drug product of XC8 and placebo were produced by Hennig $\mathrm{GmbH}$ (Germany). The XC8 and the placebo tablets had identical appearance, shape, color, labeling, and packaging.

\section{Endpoints}

The primary efficacy endpoint was defined as a change in $\mathrm{FEV}_{1}$ (\% predicted value) at week 12 as compared to the baseline at week 0 versus placebo in patients with partly controlled asthma (as defined by GINA 2015) receiving stable treatment with low-dose ICS with or without LABA.

Secondary efficacy endpoints included a comparison of each dose of XC8 and the placebo on week 12 as compared to baseline on week 0 according to the following parameters: change in maximum PEF, change in average daily variability of PEF within a week according to the results of morning and evening peak flowmetry before taking the anti-asthmatic drugs, change in $\mathrm{FEV}_{1}$ (absolute and \% predicted) and other spirometry parameters before the use of bronchodilators such as forced vital capacity of lungs (FVC), ratio $\mathrm{FEV}_{1} / \mathrm{FVC}$, forced expiratory flow (FEF) 25-75\%, measured in absolute values and in \% predicted, change in the frequency of the use of short-acting $\beta 2$-agonists for the alleviation of symptoms of asthma, percentage of patients who achieved good control of asthma (GINA 2015) at week 6 and week 12, incidence of severe exacerbations of asthma during the 12 weeks of the study treatment, change in eosinophil counts in blood and sputum, change in serum IgE and IgG levels, and change in the content of eosinophil cationic protein and tryptase in serum. Safety was assessed based on frequency of adverse events (AEs) and serious adverse events (SAEs) of different severity using subjective complaints, laboratory data, general physical examination, vital signs assessment, and electrocardiography (ECG).

\section{Assessments}

\section{Measurement of CCL2, CXCL1O and IFN- $\gamma$}

Blood sampling for the study was performed for 83 patients at three time points: before the administration of the XC8 (week 0), at week 6 and week 12 after the treatment period with XC8 or placebo. The concentration of CCL2 in the plasma of the patients (without prior dilution) was measured using the HCYTOMAG-60 K MILLIPLEX kit in accordance with the manufacturer's protocol (EMD Millipore, Bedford, MA, USA).

The plasma concentrations of IFN- $\gamma$ and CXCL10 were determined using the Bio-Plex Pro Human Chemokine 40-plex (Bio-Rad, Hercules, CA, USA) in accordance with the manufacturer's protocol. Cytokines were analyzed in plasma samples diluted 1:4. The plates were read with Luminex MagPix (Thermo Fisher Scientific, Waltham, MA, USA). The results were calculated as mean $(\mathrm{M}) \pm$ standard deviation (SD).

\section{Statistical Analysis of the Clinical Data}

Statistical analysis for the clinical trial data was performed using The $\mathrm{R}$ Project for Statistical Computing. Unless otherwise indicated, all of the data are presented by descriptive statistics according to treatment arms and study visits (if applicable). Nominal or ordered data are presented according to absolute and relative frequencies (percentages), continuous data are presented according to the number of nonmissing observations. Normal distribution was checked by Shapiro-Wilk test. At the study visits, the changes versus baseline were compared between the groups using ANOVA test. Nominal baseline data were compared using Fisher's exact test or Mantel-Haenszel test for all treatment groups. The significance level $(\alpha)$ was $5 \%$, with power of $80 \%$.

For analysis of the primary efficacy variable, a null hypothesis $\left(H_{0}\right)$ was tested. The null 
hypothesis suggested that a treatment (XC8) group is similar or non-inferior to placebo group. The alternative hypothesis $\left(H_{\mathrm{a}}\right)$ suggested that a treatment (XC8) group is superior to placebo group by efficacy:

$$
\begin{aligned}
& H_{0}: \mu_{\mathrm{T}}-\mu_{\mathrm{R}} \leq 0 \\
& H_{\mathrm{a}}: \mu_{\mathrm{T}}-\mu_{\mathrm{R}}>0
\end{aligned}
$$

where $\mu_{\mathrm{T}}$ is the mean value for XC8 groups; $\mu_{\mathrm{R}}$ is the mean value for placebo group. The hypothesis was tested using two-side tests with Holm adjustment, $\alpha=0.05$. At each visit, the $p$ values were calculated for pairwise comparisons and presented with the use of a Holm multiplicity adjustment. To compare the ordered categories in the therapy groups with the placebo group, ANOVA model for ranked data (nonparametric statistics) or Kruskal-Wallis test and Wilcoxon test were used. This analysis was conducted in two patient's populations-modified intention-totreat (MITT) and per protocol.

To evaluate the significance of the differences between the therapeutic groups at posthoc analysis by changes in $\mathrm{FEV}_{1}$ during the trial, a two-way analysis of variance with repeated measurements (repeated measures ANOVA) was used. The $\mathrm{FEV}_{1}$ values were added as dependent variables at different study visits (week 0, 2, 6, and 12). As independent predictors, the therapeutic study arm (placebo arm, XC8 arms at doses of 2,10, and $100 \mathrm{mg}$ ), the elevated baseline at week 0 PBEC (cut-off of 300 cells $/ \mu \mathrm{l}$ ), and serum IFN- $\gamma$ level (cut-off of $100 \mathrm{pg} / \mathrm{mL}$ ) were added. To evaluate the significance of the difference, the effect of interaction between the visits, groups, PBEC, and IFN- $\gamma$ level was used. This analysis was performed in the population Completers, which included all patients from intention-to-treat (ITT) populations who had values of $\mathrm{FEV}_{1}$ at baseline (week 0 ) and at the week 12 . The missing values were completed using the Last Observation Carried Forward (LOCF) method (replacing the missing values with the previous ones). All of the statistical calculations were performed with the statistical significance level of $\alpha=0.05$.

\section{RESULTS}

\section{Baseline Characteristics of Patients}

The disposition of subjects that were randomized to receive XC8 at 2,10, and $100 \mathrm{mg}$, or a placebo at baseline week 0 is shown on Fig. 1 . Baseline demographic and asthma characteristics were generally well balanced between the treatment arms. All of the subjects in this study had previously spirometrically confirmed reversibility of obstruction (improvement in $\mathrm{FEV}_{1}$ after inhalation of a rapid action bronchodilator such as $200-400 \mu \mathrm{g}$ salbutamol). Detailed demographic characteristics are shown in Table 1. The baseline pulmonary function of patients is presented in Table 2 .

\section{Safety Profile of XC8}

A total of 120 subjects were randomized in the trial at 12 sites in the Russian Federation, 90 of them received XC8 and 30 subjects received a placebo and were included in the safety population. A total of 119 subjects were included in MITT population. One patient from the XC8 $10 \mathrm{mg}$ treatment arm was excluded from the MITT population due to the absence of $\mathrm{FEV}_{1}$ evaluations after baseline. The list of AEs (according to System Organ Class and Preferred Term, MedDRA, version 20.1) and SAEs, the percentage of the subjects with AEs for every treatment arm (along with the total numbers of AEs) are summarized in electronic Supplementary Table S2 for details.

The proportion of subjects with AEs during the study was similar for placebo (18 AEs in 9/30 (30\%) subjects) and XC8 groups: 20 AEs in 8/30 $(26.70 \%)$ subjects in XC8 $2 \mathrm{mg}$ group, $10 \mathrm{AEs}$ in $6 / 30(20 \%)$ subjects in XC8 $10 \mathrm{mg}$ group, and nine AEs in 6/30 (20\%) subjects in XC8 $100 \mathrm{mg}$ group. All of these AEs were considered as not related or unlikely related to the study drug. Statistically significant differences between the treatment arms in the number of patients with AEs were not observed. One SAE (exacerbation of asthma, designated as asthma) was registered in $1 / 30(3.30 \%)$ subject in the XC8 $2 \mathrm{mg}$ group. It was classified as a SAE due to hospitalization. 


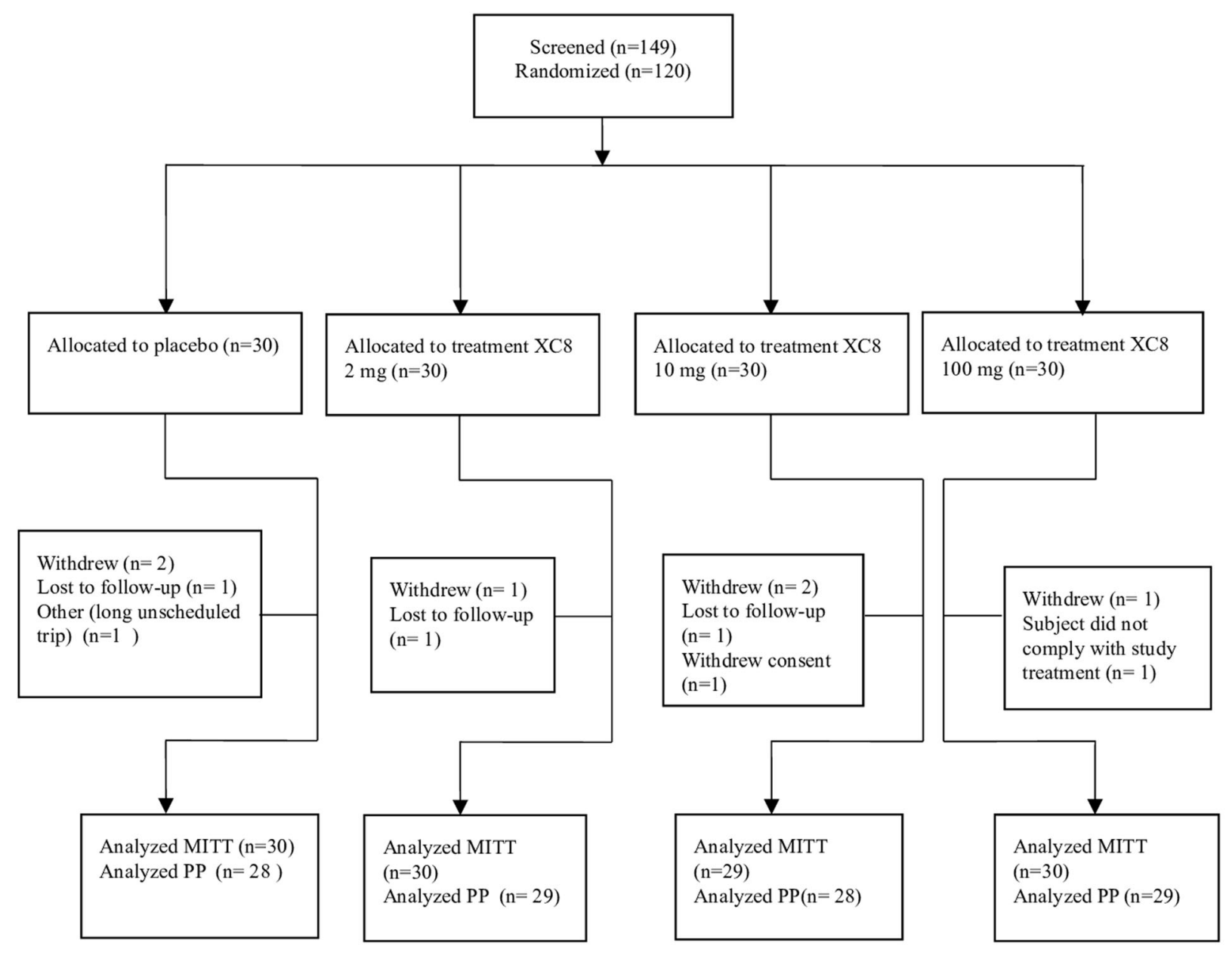

Fig. 1 Subject disposition

This SAE was considered as not related to the study drug. No cases of death, early withdrawal, or discontinuation of the investigated therapy due to AEs were observed.

\section{Efficacy of XC8}

The primary endpoint defined as statistically significant difference in $\mathrm{FEV}_{1} \%$ predicted compared to placebo at week 12 was not achieved for any of the XC8 dose groups.

However, all dose groups of XC8 showed the improvement in $\mathrm{FEV}_{1}$ at week 12 compared to baseline (Table 3, Fig. 2). The largest statistically significant change in $\mathrm{FEV}_{1}$ compared to baseline was observed for the 100-mg dose group comprising $7.40 \%$ predicted and $0.24 \mathrm{~L}(n=29$, $p<0.001)$. The placebo group showed a statistically significant improvement in the $\mathrm{FEV}_{1}$ change at week 12 from week 0 with a mean change of $4.10 \%$ predicted and $0.14 \mathrm{~L}(n=29$, $p<0.05)$.

The secondary endpoints, defined as statistically significant difference versus the placebo at week 12, were not achieved for any of the XC8 dose groups. The statistically significant change at week 12 compared to baseline was shown for XC8 $100 \mathrm{mg}$ in the daily variation of PEF $(-3.30 \%, n=29, p<0.05)$, in relative changes of FVC $(5.80 \%, p<0.05)$, in absolute change in FVC $(0.25 \mathrm{~L}, p<0.001)$, in FEF $25-75 \%$ change $(8.20 \%, p<0.05)$, and in absolute FEF $25-75 \%$ change $(0.33 \mathrm{~L} / \mathrm{s}, p<0.01)$. For the placebo-treated group, the statistically significant improvement was shown for PEF 
Table 1 Demographic and clinical characteristics of patients (MITT population)

\begin{tabular}{|c|c|c|c|c|}
\hline Parameter & $\begin{array}{l}\text { Placebo } \\
n=30\end{array}$ & $\begin{array}{l}\text { XC8 } 2 \mathrm{mg} \\
n=30\end{array}$ & $\begin{array}{l}\text { XC8 } 10 \mathrm{mg} \\
n=29\end{array}$ & $\begin{array}{l}\text { XC8 } \\
100 \mathrm{mg} \\
n=30\end{array}$ \\
\hline Age (years), mean (SD) & $48.2(13.8)$ & $47.5(13.4)$ & $48.3(12.8)$ & $51.5(10.7)$ \\
\hline \multicolumn{5}{|l|}{ Gender } \\
\hline Male $[n(\%)]$ & $5(16.7 \%)$ & $14(46.7 \%)$ & $10(34.5 \%)$ & $16(53.3 \%)$ \\
\hline Female $[n(\%)]$ & $25(83.3 \%)$ & $16(53.3 \%)$ & $19(65.5 \%)$ & $14(46.7 \%)$ \\
\hline Race, Caucasian $[n(\%)]$ & $30(100.0 \%)$ & $30(100.0 \%)$ & $29(100.0 \%)$ & $30(100.0 \%)$ \\
\hline Height $(\mathrm{cm})[$ mean $(\mathrm{SD})]$ & $168.1(9.9)$ & $168.3(9.4)$ & $169.2(8.5)$ & $171.0(8.8)$ \\
\hline Weight $(\mathrm{kg})[$ mean $(\mathrm{SD})]$ & $76.1(13.8)$ & $77.0(16.3)$ & $79.0(18.6)$ & $81.9(16.7)$ \\
\hline BMI $\left(\mathrm{kg} / \mathrm{m}^{2}\right)[$ mean $(\mathrm{SD})]$ & $27.1(5.6)$ & $27.1(4.8)$ & $27.5(5.3)$ & $28.0(5.1)$ \\
\hline Duration of asthma (years) [mean (SD)] & $9.5(8.0)$ & $10.6(9.6)$ & $8.8(8.4)$ & $11.1(9.8)$ \\
\hline \multicolumn{5}{|l|}{$\begin{array}{l}\text { The patient has been receiving stable treatment with low doses } \\
\text { ICS for at least } 3 \text { months prior to screening }\end{array}$} \\
\hline With LABA $[n(\%)]$ & $18(60.0 \%)$ & $18(60.0 \%)$ & $18(62.1 \%)$ & $22(73.3 \%)$ \\
\hline Without LABA $[n(\%)]$ & $12(40.0 \%)$ & $12(40.0 \%)$ & $11(37.9 \%)$ & $8(26.7 \%)$ \\
\hline \multicolumn{5}{|l|}{ Steps of asthma therapy (GINA, 2015) } \\
\hline Step $1[n(\%)]$ & $0(0.0 \%)$ & $0(0.0 \%)$ & $0(0.0 \%)$ & $0(0.0 \%)$ \\
\hline Step $2[n(\%)]$ & $15(50.0 \%)$ & $14(46.7 \%)$ & $14(48.3 \%)$ & $11(36.7 \%)$ \\
\hline Step $3[n(\%)]$ & $15(50.0 \%)$ & $16(53.3 \%)$ & $15(51.7 \%)$ & $19(63.3 \%)$ \\
\hline $\begin{array}{l}\text { Frequency of the use of short-acting } \beta 2 \text {-agonists, per week, mean } \\
(\text { SD) }(n)\end{array}$ & $\begin{array}{l}4.0(2.3) \\
n=27\end{array}$ & $\begin{array}{l}5.1(5.4) \\
n=26\end{array}$ & $\begin{array}{l}4.7(3.3) \\
n=21\end{array}$ & $\begin{array}{l}4.9(4.9) \\
n=24\end{array}$ \\
\hline \multicolumn{5}{|l|}{ Smoking history } \\
\hline Non-smoker $[n(\%)]$ & $30(100.0 \%)$ & $29(96.7 \%)$ & $27(93.1 \%)$ & $28(93.3 \%)$ \\
\hline Current smoker $[n(\%)]$ & $0(0.0 \%)$ & $0(0.0 \%)$ & $0(0.0 \%)$ & $0(0.0 \%)$ \\
\hline Ex-smoker $[n(\%)]$ & $0(0.0 \%)$ & $1(3.3 \%)$ & $2(6.9 \%)$ & $2(6.7 \%)$ \\
\hline \multicolumn{5}{|l|}{ Alcohol use history } \\
\hline Non-alcohol user $[n(\%)]$ & $28(93.3 \%)$ & $28(93.3 \%)$ & $28(96.6 \%)$ & $29(96.7 \%)$ \\
\hline Current alcohol user $[n(\%)]$ & $2(6.7 \%)$ & $2(6.7 \%)$ & $1(3.4 \%)$ & $1(3.3 \%)$ \\
\hline Ex-alcohol user $[n(\%)]$ & $0(0.0 \%)$ & $0(0.0 \%)$ & $0(0.0 \%)$ & $0(0.0 \%)$ \\
\hline
\end{tabular}

$n$ number of patients, $S D$ standard deviation, $B M I$ body mass index 
Table 2 Baseline pulmonary function of patients (MITT population)

\begin{tabular}{lllll}
\hline Outcome & $\begin{array}{l}\text { Placebo } \\
\boldsymbol{n}=\mathbf{3 0}\end{array}$ & $\begin{array}{l}\text { XC8 2 mg } \\
\boldsymbol{n}=\mathbf{3 0}\end{array}$ & $\begin{array}{l}\text { XC8 10 mg } \\
\boldsymbol{n}=\mathbf{2 9}\end{array}$ & $\begin{array}{l}\text { XC8 100 mg } \\
\boldsymbol{n}=\mathbf{3 0}\end{array}$ \\
\hline FEV $_{1} \%$ predicted, baseline, mean (SD) & $72.5(6.1)$ & $68.6(5.8)$ & $71.8(6.6)$ & $71.2(6.0)$ \\
FEV $_{1}$ (L), baseline, mean (SD) & $2.23(0.60)$ & $2.24(0.48)$ & $2.32(0.49)$ & $2.34(0.55)$ \\
PEF (L/min), baseline, mean (SD) & $360.0(97.0)$ & $375.8(83.0)$ & $362.3(103.3)$ & $381.5(98.5)$ \\
Average daily variability PEF, \%, baseline, mean (SD) & $9.5(6.6)$ & $10.6(6.4)$ & $8.0(5.4)$ & $9.3(6.3)$ \\
FVC \%, baseline, mean (SD) & $81.9(10.2)$ & $82.8(11.7)$ & $77.6(11.1)$ & $85.0(14.3)$ \\
FVC (L), baseline, mean (SD) & $3.07(0.76)$ & $3.33(0.82)$ & $3.12(0.76)$ & $3.50(1.08)$ \\
FEF 25-75\%, \%, baseline, mean (SD) & $53.2(14.0)$ & $46.8(19.0)$ & $63.3(28.3)$ & $50.3(14.7)$ \\
FEF 25-75\%, L/s, baseline, mean (SD) & $1.74(0.70)$ & $1.62(0.65)$ & $2.04(0.91)$ & $1.65(0.59)$ \\
\hline
\end{tabular}

$n$ number of patients, $S D$ standard deviation

$(-3.70 \%, n=29, p<0.01)$, and for $\mathrm{FVC}$, respectively $4.20 \%(p<0.05)$ and $0.16 \mathrm{~L}$ $(p<0.05)$. No statistically significant changes at week 12 compared to baseline were revealed in the frequency of the use of short-acting $\beta 2$-agonists for the alleviation of asthma symptoms, in the frequency of severe exacerbations of asthma, in blood and sputum eosinophil count, in serum $\operatorname{IgE}$ and $\operatorname{IgG}$, or in the content of serum eosinophil cationic protein (data not shown).

\section{Additional Post Hoc Analysis of Study Results}

The investigation of the mechanism of action of XC8 allowed to hypothesize that the effect of XC8 could depend on the initial PBEC and IFN$\gamma$ level. Therefore, we performed a post hoc analysis of the study results and evaluated the efficacy of XC8 in patients according to the initial PBEC (cut-off of 300 cells/ $\mu \mathrm{l}$ ) and serum IFN- $\gamma$ level (cut-off of $100 \mathrm{pg} / \mathrm{mL}$ ). We have also analyzed the effect of XC8 on the level of CCL2, known as strong eosinophil chemoattractant, and CXCL10 (IFN- $\gamma$ inducible protein). This analysis was performed for the population of patients that completed the study and had estimates of the $\mathrm{FEV}_{1}$ at baseline week 0 and at the week 12 (Table 4 ).
No statistically significant improvement in the $\mathrm{FEV}_{1}$ at week 12 from week $0(0.07 \mathrm{~L}$ and $1.20 \%$ predicted, $n=10$ ) was shown for placebo-treated patients with positive PBEC ( $>300$ cells $/ \mu \mathrm{L}$ ) status. While placebo-treated patients with negative PBEC status showed statistically significant change in the $\mathrm{FEV}_{1}$ with a mean value of $5.89 \%$ predicted $(n=18, p<0.05)$. Treatment of patients with elevated PBEC with XC8 $100 \mathrm{mg}$ resulted in a statistically significant change in $\mathrm{FEV}_{1}$ of $0.39 \mathrm{~L}(n=12, p<0.05$, compared to baseline) and $11.33 \%$ predicted ( $p<0.05$, compared to the baseline versus the placebo). While no statistically significant improvement in $\mathrm{FEV}_{1}$ was revealed for patients with negative PBEC status treated with XC8. Patients receiving placebo did not show a statistically significant change in CCL2 regardless of positive $(73.77 \mathrm{pg} / \mathrm{mL}, \mathrm{n}=9)$ or negative $(23.30 \mathrm{pg} / \mathrm{mL}, n=10)$ PBEC status. Whereas treatment of all patients with XC8 $100 \mathrm{mg}$ resulted in the decrease in CCL2 level. The mean change in CCL2 for patients with positive PBEC status was statistically significant $(-111 \mathrm{pg} / \mathrm{mL}, n=9, p<0.05)$ as compared to the baseline versus the placebo.

Treatment of patients with elevated serum IFN- $\gamma$ level $(>100 \mathrm{pg} / \mathrm{mL})$ with placebo resulted in decline in $\mathrm{FEV}_{1}(-3.11 \%$ predicted, $n=9)$ indicating the resistance of these patients to the 
Table 3 Efficacy outcomes

\begin{tabular}{|c|c|c|c|c|}
\hline Outcome & $\begin{array}{l}\text { Placebo } \\
n=29\end{array}$ & $\begin{array}{l}\text { XC8 } 2 \mathrm{mg} \\
n=29\end{array}$ & $\begin{array}{l}\text { XC8 } 10 \mathrm{mg} \\
n=28\end{array}$ & $\begin{array}{l}\text { XC8 } 100 \mathrm{mg} \\
n=29\end{array}$ \\
\hline $\begin{array}{l}\text { Change in } \mathrm{FEV}_{1} \% \text { predicted, baseline to week } 12 \text {, mean } \\
\text { (SD) }\end{array}$ & $4.1(10.1)^{*}$ & $4.1(11.2)$ & $3.7(13.6)$ & $7.4(10.8)^{* * *}$ \\
\hline Change in $\mathrm{FEV}_{1}$ (liters), baseline to week 12 , mean (SD) & $0.14(0.33)^{*}$ & $0.11(0.34)$ & $0.11(0.44)$ & $0.24(0.35)^{* *}$ \\
\hline $\begin{array}{l}\text { Change in max PEF (liters/min), baseline to week 12, mean } \\
\text { (SD) }\end{array}$ & $5.8(53.3)$ & $6.7(72.9)$ & $8.7(52.3)$ & $12.4(47.4)$ \\
\hline $\begin{array}{l}\text { Change in average daily variability PEF in \%, baseline to } \\
\text { week } 12 \text {, mean }(\mathrm{SD})\end{array}$ & $-3.7(7.8)^{* *}$ & $-5.5(6.6)^{* *}$ & $-3.5(5.7)^{* *}$ & $-3.3(6.9)^{*}$ \\
\hline Change in FVC \%,baseline to week 12, mean (SD) & $4.2(9.9)^{*}$ & $2.1(13.3)$ & $5.1(14.3)$ & $5.8(9.4)^{*}$ \\
\hline Change in FVC (liters),baseline to week 12, mean (SD) & $0.16(0.35)^{*}$ & $0.03(0.53)$ & $0.18(0.57)$ & $0.25(0.36)^{* * *}$ \\
\hline $\begin{array}{l}\text { Change in FEF } 25-75 \% \text { in \%, baseline to week } 12 \text {, mean } \\
\text { (SD) }\end{array}$ & $3.0(16.2)$ & $3.8(14.1)$ & $1.3(16.1)$ & $8.2(16.8)^{*}$ \\
\hline $\begin{array}{l}\text { Change in FEF } 25-75 \% \text { (liters/s), baseline to week 12, } \\
\text { mean (SD) }\end{array}$ & $0.12(0.60)$ & $0.14(0.67)$ & $0.06(0.53)$ & $0.33(0.55)^{* *}$ \\
\hline
\end{tabular}

$n$ number of patients

*Indicates $p<0.05$

** Indicates $p<0.01$

${ }^{* * *}$ Indicates $p<0.001$-difference is statistically significant at week 12 compared to baseline, Holm correction

therapy with ICS with or without LABA. However, a statistically significant improvement in the $\mathrm{FEV}_{1}$ was recorded for patients of placebo group with low $(<100 \mathrm{pg} / \mathrm{mL})$ initial IFN- $\gamma$ level (9.00\% predicted, $n=9, p<0.01$ ). Treatment of patients with positive IFN- $\gamma$ status with XC8 $100 \mathrm{mg}$ resulted in statistically significant change in $\mathrm{FEV}_{1}$ of $0.25 \mathrm{~L}(n=13, p<0.05$, compared to baseline) and $8.69 \%$ predicted, $(p<0.001$, compared to the baseline versus the placebo). Treatment of these patients with XC8 $100 \mathrm{mg}$ also resulted in statistically significant decrease in CXCL10 $(-353.9 \mathrm{pg} / \mathrm{mL}, n=13$, $p<0.05)$ as compared to baseline versus the placebo. For patients treated with placebo a mean change in CXCL10 was not statistically significant regardless of positive $(41.80 \mathrm{pg} / \mathrm{mL}$, $n=9)$ or negative $(-27.40 \mathrm{pg} / \mathrm{mL}, n=10) \mathrm{IFN}-\gamma$ status.

The effect of XC8 on patients with positive status of both PBEC and serum IFN- $\gamma$ was even more pronounced (Table 5). Treatment of these patients with XC8 $100 \mathrm{mg}$ resulted in statistically significant improvement in $\mathrm{FEV}_{1}$ $(0.36 \mathrm{~L}$ and $12.83 \%$ predicted, $n=6, p<0.05)$ at week 12 as compared to the baseline versus the placebo. In patients receiving placebo, a statistically significant improvement in $\mathrm{FEV}_{1}$ was observed only in patients with negative status of both PBEC and IFN- $\gamma(0.30 \mathrm{~L}$ and $10.67 \%$ predicted, $n=6, p<0.05$ ).

\section{DISCUSSION}

Despite the failure to reach the primary endpoint of the trial, defined as statistically significant change in the $\mathrm{FEV}_{1} \%$ predicted at week 12 as compared to baseline versus placebo, treatment of asthma patients with XC8 in addition to ICS with or without LABA demonstrated promising results. A statistically and clinically significant changes in $\mathrm{FEV}_{1} \%$ predicted and in absolute $\mathrm{FEV}_{1}$ values at week 12 as compared to baseline were demonstrated for the XC8 $100 \mathrm{mg}$ group. The improvement in $\mathrm{FEV}_{1} \%$ predicted 


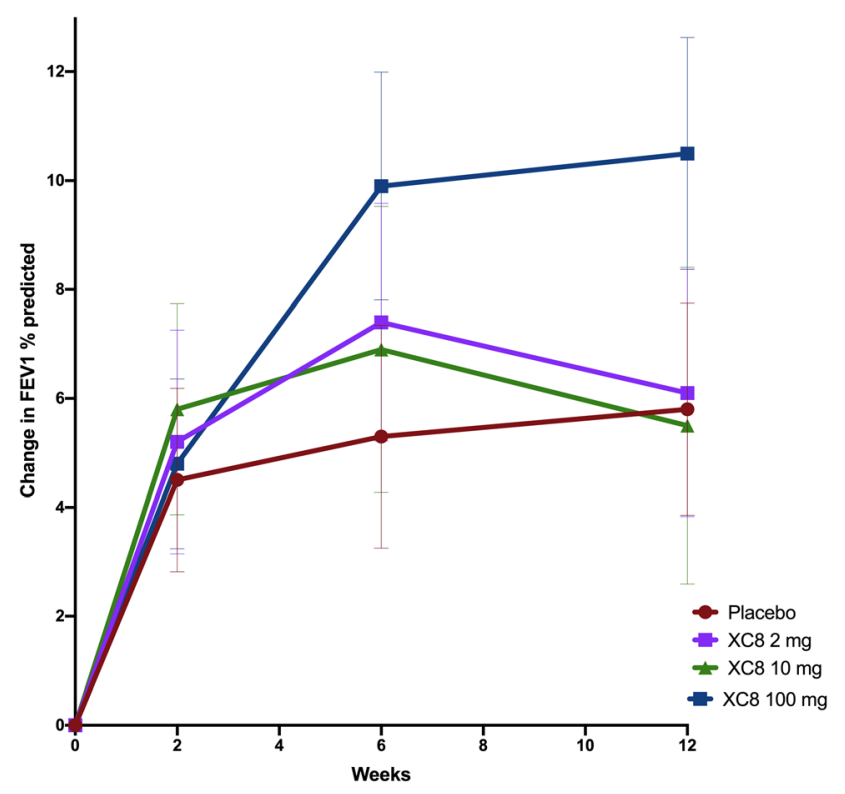

Fig. 2 Change in $\mathrm{FEV}_{1}$ (\% predicted) at week 12 relative to baseline week 0. Data are presented as mean (M) with 95\% confidence interval (CI)

from the baseline for this group was $10.50 \%$. Such magnitude of improvement in $\mathrm{FEV}_{1}$ is considered clinically important according to Santanello et al. [28]. According to the results obtained by these authors, a minimal level of $\mathrm{FEV}_{1}$ change equal to $0.23 \mathrm{~L}$ or $10.38 \%$ predicted from the baseline was required for a patient to feel the benefits. The minimal clinically significant change of $10 \%$ predicted in $\mathrm{FEV}_{1}$ is also indicated in the American Thoracic Society [29]. For the groups treated with XC8 $2 \mathrm{mg}$, and XC8 $10 \mathrm{mg}$ changes in $\mathrm{FEV}_{1} \%$ predicted and in absolute values from the baseline were not significantly different.

In order to address the high level of heterogeneity among asthma patients that could affect the response to the XC8 therapy, a post hoc analysis was performed. We have evaluated the efficacy of XC8 treatment in patients according to the initial PBEC and serum IFN- $\gamma$ level. Patients with elevated PBEC (> 300 cells/ $\mu \mathrm{l})$ treated with XC8 $100 \mathrm{mg}$ achieved a statistically and clinically significant improvement in $\mathrm{FEV}_{1}$ (11.33\% predicted) as compared to baseline versus placebo-treated with ICS with or without LABA. In this subpopulation of patients, a statistically significant decrease in CCL2 chemokine level from baseline versus placebo group was observed.

Patients with elevated initial serum IFN- $\gamma$ level $(>100 \mathrm{pg} / \mathrm{mL})$ treated with XC8 $100 \mathrm{mg}$ for 12 weeks also achieved a statistically significant improvement in $\mathrm{FEV}_{1}$ values $(0.25 \mathrm{~L}$ or $8.69 \%$ predicted) as compared to baseline versus placebo. Additionally, in this subpopulation of patients (dose XC8 $100 \mathrm{mg}$, positive IFN- $\gamma$ status), a statistically significant decrease in CXCL10 chemokine level as compared to baseline versus placebo was observed.

In a subpopulation of patients with positive initial both PBEC and IFN- $\gamma$ status, a statistically significant improvement in $\mathrm{FEV}_{1}$ values compared to baseline versus placebo group was observed for a dose of XC8 $100 \mathrm{mg}(0.36 \mathrm{~L}$ or $12.83 \%$ predicted).

The mechanism of action of XC8 is related to the inhibition of gQC, the enzyme that catalyzes the pyroglutamination of $\mathrm{C}-\mathrm{C}$ motif chemokines. The posttranslational modification protects these chemokines from proteolysis and thus supports their functioning [30, 31]. Pyroglutaminated chemokines CCL2, CCL8, 
Table 4 Efficacy outcomes according to eosinophilic and IFN- $\gamma$ status (population completers)

\begin{tabular}{lllllll}
\hline Outcome & $\begin{array}{l}\text { PBEC or IFN- } \gamma \\
\text { status }\end{array}$ & Placebo & XC8 $2 \mathrm{mg}$ & XC8 $10 \mathrm{mg}$ & XC8 $100 \mathrm{mg}$ \\
\hline
\end{tabular}

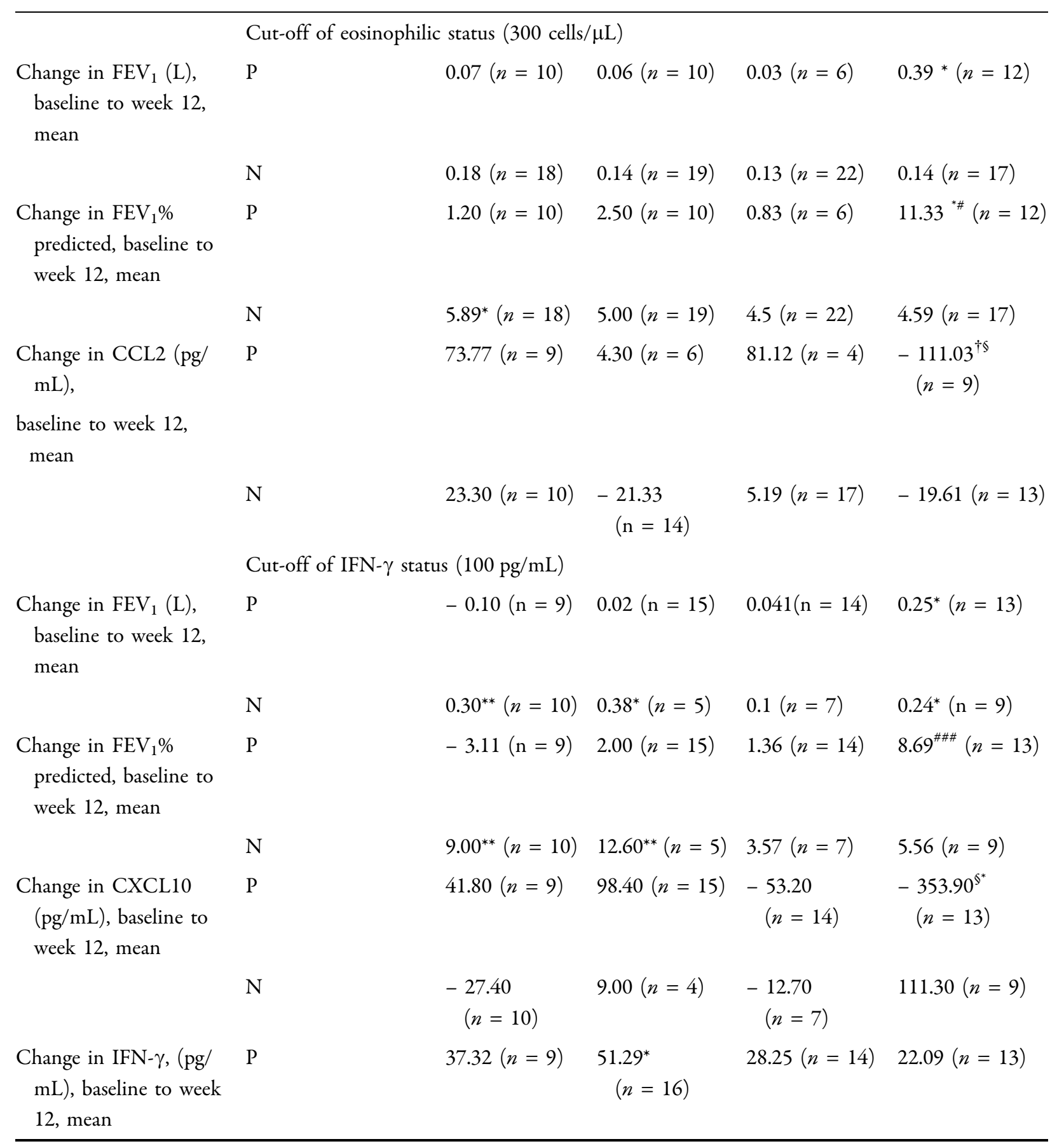


Table 4 continued

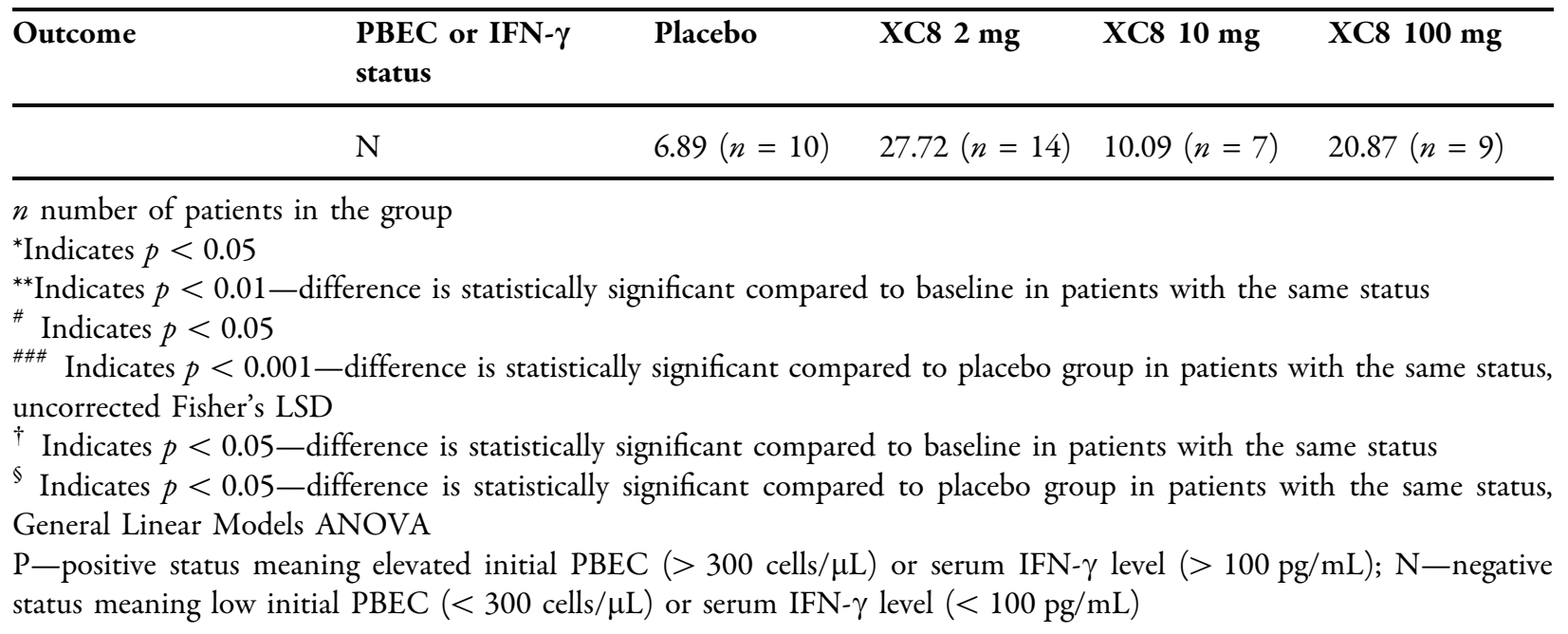

CCL7, and CCL13 were shown to interact with specific receptors CCR1, CCR2, CCR3 on the surface of different immune cells [24]. It has been demonstrated that functional CCR2 receptor is expressed on the surface of eosinophils, and CCL2, CCL8, CCL7, and CCL13 chemokines can serve as strong eosinophil chemoattractants $[25,26]$. Therefore, by inhibiting gQC, XC8 reduces the activity of CCL2, CCL8, CCL7, and CCL13 chemokines and the eosinophil-driven inflammation.

The second important property of XC8 is its effect on IFN- $\gamma$ signaling. We have shown that the treatment of mice stimulated with IFN- $\gamma$ with XC8 resulted in decrease in neutrophil count in the BAL, which correlated with the decrease in CXCL10 level, known as IFN- $\gamma$ inducible protein (unpublished data). These preclinical data are consistent with the effect observed in patients of this trial with elevated initial level of serum IFN- $\gamma$. Treatment of these patients with XC8 $100 \mathrm{mg}$ in addition to ICS (with or without LABA), but not with ICS alone, led to a decrease in CXCL10 level and to an improvement in $\mathrm{FEV}_{1}$.

Asthma is a disease, driven by Th 2 cytokines, particularly by IL-4 and IL-5 [32]. However, IFN$\gamma$ (the principal Th1 effector cytokine), is also involved in the asthma pathogenesis. Elevated level of IFN- $\gamma$ is found in patients with more severe inflammatory airway disease and increased proinflammatory response [33-35]. Some trials have demonstrated that elevated level of IFN- $\gamma$ correlates with resistance to ICS in patients with asthma [36] or COPD [37]. It was shown that possible mechanism of decreased responsiveness to ICS is induced by the activation of Janus kinase (JAK)/signal transducers and activators of transcription (STAT) signaling pathway by IFN- $\gamma$ [38]. Here we have demonstrated that XC8 affects the IFN- $\gamma$ inducible protein CXCL10. These results open the possibility to restore the responsiveness to ICS by treatment of patients with XC8. This effect of XC8 can be of particular importance for the treatment of patients who do not respond properly to treatment with ICS with or without LABA.

The efficacy of XC8 is comparable to that of some mAbs. The treatment of patients having moderate-to-severe uncontrolled asthma with tralokinumab (anti-IL-13 mAb) for 13 weeks led to the increase in $\mathrm{FEV}_{1}$ of $0.21 \mathrm{~L}$ [39], and the use of reslizumab (anti-IL-5 mAb) for the treatment of patients inadequately controlled by medium-to-high doses of ICS for one year led to the improvement of $0.18 \mathrm{~L}_{\text {in }} \mathrm{FEV}_{1}$ [40]. On the other hand, treatment of patients with eosinophilic asthma with mepolizumab (anti-IL-5 $\mathrm{mAb}$ ) significantly decreased the number of severe exacerbations, but did not change significantly the $\mathrm{FEV}_{1}$ over the course of treatment 
Table $5 \mathrm{FEV}_{1}$ changes by the end of the study (week 12) compared with the baseline (week 0 ) in patients with a combined $(\mathrm{PBEC}$ and IFN- $\gamma$ ) status

\begin{tabular}{|c|c|c|c|c|c|}
\hline Outcome & $\begin{array}{l}\text { Combined } \\
\text { PBEC and } \\
\text { IFN- } \gamma \\
\text { status }\end{array}$ & Placebo & XC8 $2 \mathrm{mg}$ & XC8 $10 \mathrm{mg}$ & XC8 $100 \mathrm{mg}$ \\
\hline \multirow{8}{*}{$\begin{array}{l}\text { Change in } \\
\mathrm{FEV}_{1}(\mathrm{~L}) \text {, } \\
\text { baseline to } \\
\text { week } 12 \text {, } \\
\text { mean }(95 \% \\
\mathrm{CI})\end{array}$} & NN & $0.30^{*}(0.01 ; 0.59)$ & $0.39(-0.02 ; 0.79)$ & $0.06(-0.25 ; 0.38)$ & $0.15(-0.14 ; 0.44)$ \\
\hline & & $(n=6)$ & $(n=3)$ & $(n=5)$ & $(n=6)$ \\
\hline & PN & $0.30(-0.05 ; 0.65)$ & $0.38(-0.12 ; 0.87)$ & $0.25(-0.25 ; 0.75)$ & $0.43^{*}(0.02 ; 0.80)$ \\
\hline & & $(n=4)$ & $(n=2)$ & $(n=2)$ & $(n=3)$ \\
\hline & NP & $-0.05(-0.40 ; 0.30)$ & $0.08(-0.13 ; 0.29)$ & $0.12(-0.08 ; 0.32)$ & $0.16(-0.10 ; 0.43)$ \\
\hline & & $(n=4)$ & $(n=11)$ & $(n=12)$ & $(n=7)$ \\
\hline & $\mathrm{PP}$ & $-0.14(-0.46 ; 0.17)$ & $-0.13(-0.48 ; 0.22)$ & $-0.44(-0.94 ; 0.06)$ & $0.36^{* \#}(0.07 ; 0.65)$ \\
\hline & & $(n=5)$ & $(n=4)$ & $(n=2)$ & $(n=6)$ \\
\hline \multirow{8}{*}{$\begin{array}{l}\text { Change in } \\
\text { FEV }_{1}(\% \\
\text { predicted), } \\
\text { baseline to } \\
\text { week 12, } \\
\text { mean ( } 95 \% \\
\mathrm{CI})\end{array}$} & NN & $10.67^{*}(3.45 ; 17.89)$ & $14.33^{*}(4.12 ; 24.55)$ & $2.60(-5.31 ; 10.51)$ & $5.17(-2.05 ; 12.39)$ \\
\hline & & $(n=6)$ & $(n=3)$ & $(n=5)$ & $(n=6)$ \\
\hline & $\mathrm{PN}$ & $6.50(-2.34 ; 15.34)$ & $10.00(-2.51 ; 22.51)$ & $6.00(-6.51 ; 18.51)$ & $6.33(-3.88 ; 16.55)$ \\
\hline & & $(n=4)$ & $(n=2)$ & $(n=2)$ & $(n=3)$ \\
\hline & NP & $-1.25(-10.09 ; 7.59)$ & $3.27(-2.06 ; 8.61)$ & $3.67(-1.44 ; 8.77)$ & $5.14(-1.54 ; 11.83)$ \\
\hline & & $(n=4)$ & $(n=11)$ & $(n=12)$ & $(n=7)$ \\
\hline & $\mathrm{PP}$ & $-4.60(-12.51 ; 3.31)$ & $-1.50^{\#}(-10.34 ; 7.34)$ & $-12.50(-25.01 ; 0.01)$ & $12.83^{* \#}(5.61 ; 20.05)$ \\
\hline & & $(n=5)$ & $(n=4)$ & $(n=2)$ & $(n=6)$ \\
\hline
\end{tabular}

$n$ number of patients

${ }^{*}$ Indicates $p<0.05$ - the difference is statistically significant compared to baseline in patients with the same combined status, uncorrected Fisher's LSD

\# Indicates $p<0.05$ - the difference is statistically significant compared to placebo group in patients with the same combined status, Mann-Whitney test

$\mathrm{P}-$ positive status meaning elevated initial PBEC $(>300$ cells $/ \mu \mathrm{l})$ or serum IFN- $\gamma$ level $(>100 \mathrm{pg} / \mathrm{mL}), \mathrm{N}-$ negative status meaning low initial PBEC $(<300$ cells $/ \mu \mathrm{L})$ or serum IFN- $\gamma$ level $(<100 \mathrm{pg} / \mathrm{mL})$ 
for 50 weeks [41]. Given the good safety profile and tolerability as well as the oral route of administration, XC8 may provide a good treatment option for patients with mild-to-moderate disease.

The presented trial is the first to evaluate the efficacy of XC8. The small size of the groups is a limiting factor of this study. This factor is particularly important for the post hoc analysis where the comparison of subpopulations of patients with elevated PBEC and IFN- $\gamma$ level was performed. A higher number of patients per group would also allow to perform a separate analysis of efficacy in patients treated with ICS alone or with ICS in combination with LABA.

\section{CONCLUSIONS}

To conclude, the treatment of patients with XC8 (100 mg) over 12 weeks resulted in clinically meaningful increase in $\mathrm{FEV}_{1}$ relative to the baseline. Therapeutic efficacy of XC8 was more pronounced in patients with elevated PBEC and/or serum IFN- $\gamma$ level. The improvement in $\mathrm{FEV}_{1}$ values for these patients was statistically significant as compared to baseline versus placebo. Pharmacodynamic engagement was demonstrated by a reduction in serum level of CCL2 and CXCL10 chemokines. Treatment of patients with elevated serum IFN- $\gamma$ levels with XC8 (100 mg) alleviated the resistance to the therapy with ICS. Further investigation of XC8 in phase IIb clinical trial is warranted.

\section{ACKNOWLEDGEMENTS}

We thank all the participants of the study.

Funding. The clinical trial was financed by the LLC PHARMENTERPRISES (Moscow, Russia) and supported by the Ministry of Industry and Trade of the Russian Federation. The government contract No. 14411.2049999.19.031 from $8 / 4 / 2014$ is named "Organizing and conducting of clinical trials of an innovative drug for the treatment of asthma". Drug substance manufacturing was financed by LLC
PHARMENTERPRISES, the manufacturing of the drug product was financed by EURRUS Biotech GmbH (Tulln, Austria). The journal's Rapid Service and Open Access Fees are paid by EURRUS Biotech GmbH. EURRUS Biotech $\mathrm{GmbH}$ has the license for the clinical development of XC8 and holds the exclusive international marketing license. The clinical trial was performed under the supervision of IPHARMA C.R.O. (Russia).

Editorial Assistance. The editorial assistance was provided by co-author Prof. W. Pohl (Karl Landsteiner Institute for Clinical and Experimental Pneumology, Hietzing Hospital, Vienna, Austria) free of charge.

Authorship. All listed authors meet the International Committee of Medical Journal Editors (ICMJE) criteria for authorship for this article, had full access to all data of the study, take the responsibility for the integrity of the study and approved current version of the manuscript.

Disclosures. Vladimir Nebolsin is the author of the project, the founder, and the Head of the company PHARMENTERPRISES LLC. Julia Romanova, Elena Chikina, Anastasia Rydlovskaya, Wolfgang Pohl, Andreas Renner, Alexey Zeifman and Alexander Chuchalin have nothing to disclose. The current affiliation of Andreas Renner is Heart and Lung Center, Helsinki University Hospital (Helsinki, Finland).

Compliance with Ethics Guidelines. All subjects provided written informed consent before participating in the study. The study was conducted in accordance with the principles of the Declaration of Helsinki and the International Conference on Harmonization Guidance for Good Clinical Practice. The study was approved by the Ethics Committee Ministry of Health of the Russian Federation, protocol 115 from 08.12.2015.

Data Availability. All data are available from the corresponding author upon request. 
Open Access. This article is licensed under a Creative Commons Attribution-NonCommercial 4.0 International License, which permits any non-commercial use, sharing, adaptation, distribution and reproduction in any medium or format, as long as you give appropriate credit to the original author(s) and the source, provide a link to the Creative Commons licence, and indicate if changes were made. The images or other third party material in this article are included in the article's Creative Commons licence, unless indicated otherwise in a credit line to the material. If material is not included in the article's Creative Commons licence and your intended use is not permitted by statutory regulation or exceeds the permitted use, you will need to obtain permission directly from the copyright holder. To view a copy of this licence, visit http:// creativecommons.org/licenses/by-nc/4.0/.

\section{REFERENCES}

1. Braman SS. The global burden of asthma. Chest. 2006;130(1 Suppl):4S-12S.

2. Global Initiative for Asthma. Global Strategy for Asthma Management and Prevention. 2015. www. ginasthma.org. Accessed 30 Dec 2015.

3. Lommatzsch M, Stoll P. Novel strategies for the treatment of asthma. Allergo J Int. 2016;25:11-7.

4. Akenroye A, McCormack M, Keet C. Severe Asthma in the US Population and Eligibility for Monoclonal Antibody Therapy. J Allergy Clin Immunol. 2020;145(4):1295-1297.e6.

5. Norman P. Update on the status of DP2 receptor antagonists; from proof of concept through clinical failures to promising new drugs. Expert Opin Investig Drugs. 2014;23(1):55-66.

6. Douwes J, Gibson P, Pekkanen J, Pearce N. Noneosinophilic asthma: importance and possible mechanisms. Thorax. 2002;57(7):643-8.

7. de Groot JC, Ten Brinke A, Bel EH. Management of the patient with eosinophilic asthma: a new era begins. ERJ Open Res. 2015;1(1):1-11.

8. Casciano J, Krishnan J, Dotiwala Z, Li C, Sun SX. Clinical and economic burden of elevated blood eosinophils in patients with and without uncontrolled asthma. J Manag Care Spec Pharm. 2017;23(1):85-91.

9. Zeiger RS, Schatz M, Li Q, Chen W, Khatry DB, Gossage D, et al. High blood eosinophil count is a risk factor for future asthma exacerbations in adult persistent asthma. J Allergy Clin Immunol Pract. 2014;2(6):741-50.

10. Lawrence MG, Steinke JW, Borish L. Cytokine-targeting biologics for allergic diseases. Ann Allergy Asthma Immunol. 2018;120(4):376-81.

11. Ramonell RP, Iftikhar IH. Effect of Anti-IL5, AntiIL5R, Anti-IL13 therapy on asthma exacerbations: a network meta-analysis. Lung. 2020;198:95-103.

12. Edris A, De Feyter S, Maes T, Joos G, Lahousse L. Monoclonal antibodies in type 2 asthma: a systematic review and network meta-analysis. Respir Res. 2019;20(1):179.

13. Park HS, Kim MK, Imai N, Nakanishi T, Adachi M, Ohta $\mathrm{K}$, et al. A phase 2a study of benralizumab for patients with eosinophilic asthma in South Korea and Japan. Int Arch Allergy Immunol. 2016;169(3): $135-45$.

14. Chupp GL, Bradford ES, Albers FC, Bratton DJ, Wang-Jairaj J, Nelsen LM, et al. Efficacy of mepolizumab add-on therapy on health-related quality of life and markers of asthma control in severe eosinophilic asthma (MUSCA): a randomised, doubleblind, placebo-controlled, parallel-group, multicentre, phase 3b trial. Lancet Respir Med. 2017;5(5): 390-400.

15. Castro M, Zangrilli J, Wechsler ME, Bateman ED, Brusselle GG, Bardin P, et al. Reslizumab for inadequately controlled asthma with elevated blood eosinophil counts: results from two multicentre, parallel, double-blind, randomised, placebo-controlled, phase 3 trials. Lancet Respir Med. 2015;3(5): 355-66.

16. Yancey SW, Ortega HG, Keene ON, Mayer B, Gunsoy $\mathrm{NB}$, Brightling $\mathrm{CE}$, et al. Meta-analysis of asthma-related hospitalization in mepolizumab studies of severe eosinophilic asthma. J Allergy Clin Immunol. 2017;139(4):1167-75.

17. Rathinam KK, Abraham JJ, Vijayakumar TM. Dupilumab in the treatment of moderate to severe asthma: an evidence-based review. Curr Ther Res Clin Exp. 2019;91:45-51.

18. Skolnik NS, Carnahan SP. Primary care of asthma: new options for severe eosinophilic asthma. Curr Med Res Opin. 2019;35(7):1309-18.

19. Rabe KF, Nair P, Brusselle G, Maspero JF, Castro M, Sher L, et al. Efficacy and Safety of Dupilumab in 
Glucocorticoid-Dependent Severe Asthma. N Engl J Med. 2018;378(26):2475-85.

20. Nebol'sin VE, Zheltukhina GA, Krzhechkovskaia VV, Kovaleva VL, Evstigneeva RP. The effect of gamma-L-glutamylhistamine analogues on the severity of experimental anaphylactic reaction, hormonal status and liver cytochrome P450 system. Vopr Med Khim. 2001;47(3):301-7.

21. Kovaleva VL, Nebol'sin VE, Makarova OV, Noseikina EM, Mikhailova LP. The effect of a potential drug ingamine on a model of noninfectious pneumonia. Eksp Klin Farmakol. 2004;67(4):30-4.

22. Kovaleva VL, Nebol'sin VE, Karabinenko AA, Zheltukhina GA, Uteshev DB. The protector properties of a pseudopeptide drug ingamine studied on a model of bronchospasm in guinea pigs. Eksp Klin Farmakol. 2005;68(2):21-4.

23. Ferko B, Romanova J, Rydlovskaya AV, Kromova TA, Proskurina OV, Amelina AN, et al. A novel oral glutarimide derivative XC8 suppresses Sephadexinduced lung inflammation in rats and ovalbumininduced acute and chronic asthma in Guinea pigs. Curr Pharm Biotechnol. 2019;20(2):146-56.

24. Proudfoot AE. Chemokine receptors: multifaceted therapeutic targets. Nat Rev Immunol. 2002;2(2): 106-15.

25. Dunzendorfer S, Kaneider NC, Kaser A, Woell E, Frade JM, Mellado M, et al. Functional expression of chemokine receptor 2 by normal human eosinophils. J Allergy Clin Immunol. 2001;108(4):581-7.

26. Deshmane SL, Kremlev S, Amini S, Sawaya BE. Monocyte chemoattractant protein-1 (MCP-1): an overview. J Interferon Cytokine Res. 2009;29(6): 313-26.

27. Renner A, Romanova J, Ferko B, Schmutz H, Nebolsin V, Muller M, et al. Safety, pharmacokinetics and pharmacodynamics of a novel antiasthmatic drug, XC8, in healthy probands. Pulm Pharmacol Ther. 2019;59:101852.

28. Santanello NC, Zhang J, Seidenberg B, Reiss TF, Barber BL. What are minimal important changes for asthma measures in a clinical trial? Eur Respir J. 1999;14(1):23-7.

29. Reddel HK, Taylor DR, Bateman ED, Boulet LP, Boushey HA, Busse WW, et al. An official American Thoracic Society/European Respiratory Society statement: asthma control and exacerbations: standardizing endpoints for clinical asthma trials and clinical practice. Am J Respir Crit Care Med. 2009;180(1):59-99.
30. Cynis H, Hoffmann T, Friedrich D, Kehlen A, Gans $\mathrm{K}$, Kleinschmidt $\mathrm{M}$, et al. The isoenzyme of glutaminyl cyclase is an important regulator of monocyte infiltration under inflammatory conditions. EMBO Mol Med. 2011;3(9):545-58.

31. Lee JS, Yang EJ, Kim IS. The roles of MCP-1 and protein kinase $\mathrm{C}$ delta activation in human eosinophilic leukemia EoL-1 cells. Cytokine. 2009;48(3):186-95.

32. Lloyd CM, Hessel EM. Functions of $\mathrm{T}$ cells in asthma: more than just $\mathrm{T}(\mathrm{H}) 2$ cells. Nat Rev Immunol. 2010;10(12):838-48.

33. Hens G, Vanaudenaerde BM, Bullens DM, Piessens M, Decramer M, Dupont LJ, et al. Sinonasal pathology in nonallergic asthma and COPD: 'united airway disease' beyond the scope of allergy. Allergy. 2008;63(3):261-7.

34. Magnan AO, Mely LG, Camilla CA, Badier MM, Montero-Julian FA, Guillot CM, et al. Assessment of the Th1/Th2 paradigm in whole blood in atopy and asthma Increased IFN-gamma-producing CD8(+) T cells in asthma. Am J Respir Crit Care Med. 2000;161(6):1790-6.

35. Litonjua AA, Sparrow D, Guevarra L, O'Connor GT, Weiss ST, Tollerud DJ. Serum interferon-gamma is associated with longitudinal decline in lung function among asthmatic patients: the Normative Aging Study. Ann Allergy Asthma Immunol. 2003;90(4):422-8.

36. Bentley AM, Hamid Q, Robinson DS, Schotman E, Meng Q, Assoufi B, et al. Prednisolone treatment in asthma. Reduction in the numbers of eosinophils, $\mathrm{T}$ cells, tryptase-only positive mast cells, and modulation of IL-4, IL-5, and interferon-gamma cytokine gene expression within the bronchial mucosa. Am J Respir Crit Care Med. 1996;153(2):551-6.

37. Kaur M, Smyth LJ, Cadden P, Grundy S, Ray D, Plumb J, et al. T lymphocyte insensitivity to corticosteroids in chronic obstructive pulmonary disease. Respir Res. 2012;13:20.

38. O'Connell D, Bouazza B, Kokalari B, Amrani Y, Khatib A, Ganther JD, et al. IFN-gamma-induced JAK/STAT, but not NF-kappaB, signaling pathway is insensitive to glucocorticoid in airway epithelial cells. Am J Physiol Lung Cell Mol Physiol. 2015;309(4):L348-L359359.

39. Piper E, Brightling C, Niven R, Oh C, Faggioni R, Poon K, et al. A phase II placebo-controlled study of tralokinumab in moderate-to-severe asthma. Eur Respir J. 2013;41(2):330-8.

40. Castro M, Mathur S, Hargreave F, Boulet LP, Xie F, Young J, et al. Reslizumab for poorly controlled, 
eosinophilic asthma: a randomized, placebo-controlled study. Am J Respir Crit Care Med. 2011;184(10):1125-32.
41. Haldar P, Brightling CE, Hargadon B, Gupta S, Monteiro W, Sousa A, et al. Mepolizumab and exacerbations of refractory eosinophilic asthma. N Engl J Med. 2009;360(10):973-84. 